\title{
PENGARUH EKSPOR MIGAS, PENANAMAN MODAL ASING, UTANG LUAR NEGERI, DAN INFLASI TERHADAP PERTUMBUHAN EKONOMI INDONESIA
}

\author{
Insyai Rina Warer ${ }^{1}$ Ni Putu Wiwin Setyari ${ }^{2}$
}

Article history:

Submitted: 20 Juni2021

Revised: 27 Juni 2021

Accepted: 17 Juli 2021

\section{Keywords:}

Oil and Gas Exports;

Foreign Investment;

ForeignDebt;

Inflation;

Indonesia's Economic Growth;

\section{Kata Kunci:}

EksporMigas;

Penanaman Modal Asing;

Utang LuarNegeri;

Inflasi;

Pertumbuhan Ekonomi

Indonesia;

\section{Koresponding:}

Fakulas Ekonomi dan Bisnis

Universitas Udayana, Bali,

Indonesia

Email:

insyairina21@gmail.com

\section{Abstract}

This study aims to analyze the partial and simultaneous effect of oil and gas exports, foreign investment, foreign debt and inflation on Indonesia's economic growth in 1975-2019. The research method uses a quantitative approach which will be explained a ssociative ly. The data analysis used is multiple linear regression method as an econometric tool to describe the characteristics of a sample or observed location with the help of SPSS 26 for windows. The results of the study prove that partially oiland gas exports, foreign debt, and inflation affect Indonesia's economic growt h. Meanwhile, foreign investment has no effect on Indonesia's economic growth. Simultaneously, the variables of oil and gas exports, foreign investment, foreign debt and inflation affect Indonesia's economic grow th. This is supported by the R2 value of 0.599 which means that 59.9 percent of the variation in economic growth is influenced by oil and gas exports, foreign investment, foreign debt and inflation, while the remaining 40.1 percent is influenced by otherfactors not included in the model.

\begin{tabular}{|c|}
\hline Abstrak \\
\hline 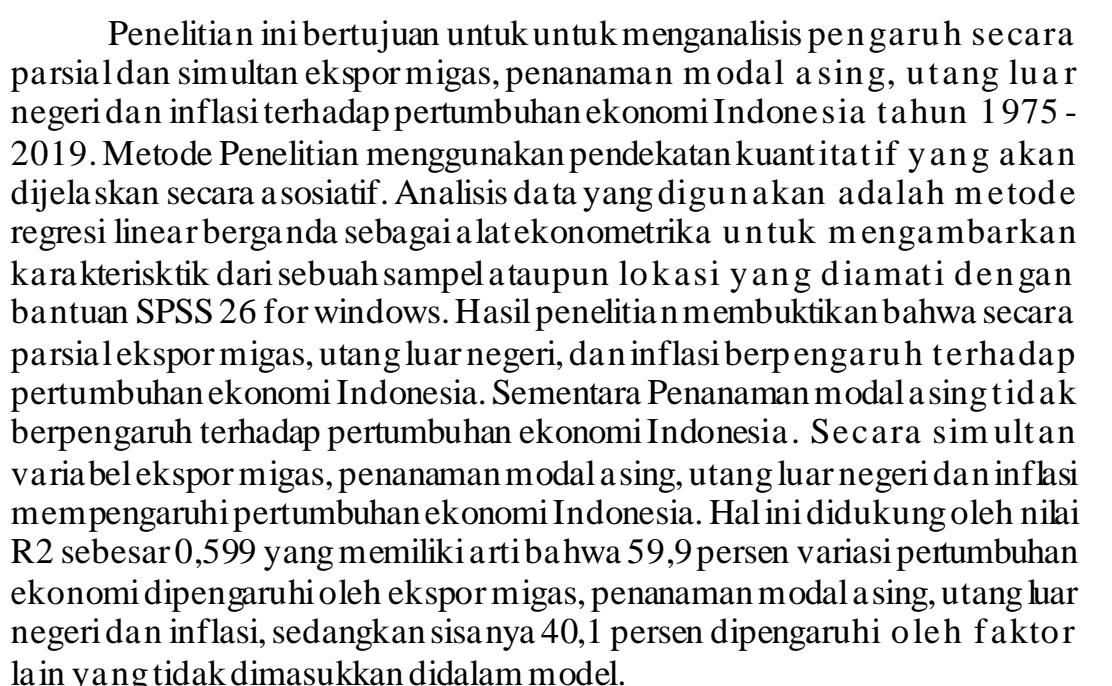 \\
\hline
\end{tabular}

Fakultas Ekonomidan Bisnis Universitas Udayana, Ba li, Indonesia ${ }^{2}$

Email: wiwin.setyari@unud.ac.id 


\section{PENDAHULUAN}

Pertumbuhan ekonomi adalah gambaran nyata dari kebijakan pembangunan yang telah dilaksanakan, khususnya pada bidang ekonomi. Laju pertumbuhan ekonomi daerah dapat dilihat melalui perkembangan produk domestic bruto. Arifin dan Gina (2009) menyebutkan bahwa PDB digunakan sebagai indicator pengukuran pertumbuhan ekonomi karena PDB dihitung berdasarkan jumlah nilai tambah (value added) yang dihasilkan seluruh aktivitas produksi didalam perekonomian. Hal ini menyebabkan peningkatan PDB mencerminkan peningkatan balas jasa kepada faktor produksi yang digunakan dalam proses produksi. Menurut Rudriger (2006), produk domestik bruto merupakan ukuran nilai pasar dari barang dan jasa akhir yang diproduksi oleh sumber daya yang berada dalam suatu negara selama jangka waktu tertentu, biasanya dalam kurun waktu satu tahun. Makadari itu, dapat dikatakan bahwa PDB memeiliki peran penting dalam perekonomian sehingga perlu untuk menganalisis faktor-faktor yang mempengaruhinya (Arsyad, 2004).

Pertumbuhan ekonomi merupakan permasalahan perekonomian dalam jangka Panjang. Pertumbuhan ekonomi juga bersangkut paut dengan proses peningkatan produksi barang dan jasa dalam kegiatan ekonomi masyarakat. Menurut Untoro (2010), pertumbuhan ekonomi adalah perkembangan kegiatan dalam perekonomian yang menyebabkan barang dan jasa yang diproduksi dalam masyarakat bertambah dan kemakmuran masyarakat meningkat dalam jangka panjang. Pada tahun 2009, Indonesia mengalami krisis untuk kedua kalinya (setelah krisis moneter tahun 1997-1998) yang disebabkan adanya krisis ekonomi Amerika Serikat yang lalu menyebar ke negara-negara lain diseluruh dunia. Meskipun dilanda krisis ekonomi, namun Indonesia bisa cepat pulih dari keadaan tersebut. Indonesia sendiri diberkahi dengan sumber daya alam yang melimpah, seperti mineral, hasil pertanian dan minyak dan gas.

Kegiatan ekspor impor memegang peranan penting dalam kegiatan ekonomi negara. Ekspor adalah penjualan barang dan jasa dari dalam negeri ke luar negeri, sedangkan impor meliputi pembelian barang dan jasa dari luar negeri kedalam negeri. Ekspor berkaitan erat dengan PDB, dimana peningkatan ekspor akan meningkatkan PDB serta kondisi ceteris paribus. Apabila impor barang lebih besar dari pada penerimaan ekspor nasional maka akan terjadi penurunan neraca pembayaran sehingga menjadi defisit (deflasi) (Hasmarini \& Murtiningsih, 2017). Bagi Indonesia, hasil sumber daya alam baik migas dan non-migas menjadi tumpuan keunggulan komparatifnsehingga dapat diperdag angkan melalui ekspor. Sebagaimana diketahui, Indonesia merupakan eksportir sekaligus importir migas, bahkan sejak tahun 2000an Indonesia telah menjadi negara net importir migas. Gas adalah komoditi yang merupakan turunan dari hasil minyak bumi dan gas bumi, sedangkan non-migas adalah barang keluar dari gas dan bumi atau barang yang tidak berupa minyak dan gas bumi seperti pertanian, perkebunan, perikanan, peternakan dan lain-lain (Sugiyono, 2017). Seiring perkembangan waktu, peranan ekspor migas terhadap ekspor nasional terus menurun. Jika diteliti lebih lanjut, penurunan yang signifikan dari nilai ekspor migas terjadi pada setiap komoditas utamanya. Defisit migas terjadi karena pergerakan minyak. Ketika harga naik maka defisit akan meningkat, dan Ketika harga menurun maka defisit akan menurun, namun tetap mengalami defisit.

Kunci untuk meningkatkan laju pertumbuhan ekonomi yang tinggi adalah pembentukan modal. Pembentukan modal dapat bersumber dari utang luar negeri maupun penanaman modal. Todaro (2006) menjelaskan bahwa penanaman modal asing adalah aliran modal internasional yang menjadi salah satu bagian penting dalam strategi pembangunan jangka panjang di negara-negara berkembang. FDI meningkatkan kemampuan produksi dan menjadi media transfer teknologi dari luar 
negeri ke dalam negeri, sehingga akan mempengaruhi pertumbuhan ekonomi di negara tuan rumah (Borenstein et al, 1998). Terbatasnya sumber dana dalam negeri membuat pemerintah memberlakukan kebijakan utang luar negeri sebagai penutup defisit (Atmadja, 2000). Penambahan utang yang dilakukan oleh pemerintah menyebabkan pembayaran cicilan pokok dan bunga dari utang tersebut makin mengalami peningkatan dari tahun ke tahun, sehingga kebijakan tersebut berpengaruh terhadap kinerja APBN yang semakin menurun (Saputra, 2016). Menurut Sukirno (2011), inflasi terjadi karena adanya permintaan, yang kemudian menyebabkan harga baran meningkat karena keterbatan jumlah barang yang tersedia. Inflasi yang tidak terkontrol akan menyebabkan penurunan pertumbuhan ekonomi, makadari itu penting untuk menjaga kestabilan inflasi agar dapat memicu pertumbuhan ekonomi karena menguntungkan industri.

Hubungan antara investasi (PMA dan PMDN) dengan pertumbuhan ekonomi adalah deng an adanya investasi berupa pembelian barang modal dan pelengkapan produksi untuk menambah kemampuan memproduksi barang-barang dan jasa yang dibutuhkan dalam perekonomian sehingga hal ini dapat meningkatkan PDB riil Indonesia dan dengan demikian akan berpengaruh positif terhadap pertumbuhan ekonomi (Tri Handayani, 2011). Hasil penelitian Fitriani (2019) menemukan bahwa ekspor berpengaruh positif terhadap pertumbuhan ekonomi. Penelitian Mariska Ishak Rudi dkk (2014) menemukan hasil bahwa Utang luar negeri dan penanaman modal asing berpengaruh positif dan signifikan terhadap pertumbuhan ekonomi. Elbadawi et.al (1997) dalam studi telah membuktikan bahwa akumulasi pinjaman luar negeri yang terjadi karena meningkatnya kebutuhan untuk melunasi utang-utang yang lalu akan berdampak negatif terhadap investasi dan pertumbuhan ekonomi setelah melampaui batas tertentu. Hasil penelitian Barro (2013) yang berjudul "Inflation and Economic Growth" menunjukkan bahwa inflasi berpengaruh signifikan negatif terhadap pertumbuhan dan investasi.

Berdasarkan rumusan masalah dan pembahasan hasil penelitian terlebih dahulu maka diajukan hipotesis sebagai berikut: H1: Diduga bahwa ekspor migas, penanaman modal asing,utang luar negeri, secara parsial berpengaruh positif dan signifikan terhadap pertumbuhan ekonomi Indonesia tahun 1975-2019. H2:Diduga bahwa inflasi secara parsial berpengaruh negatif dan signifikan terhadap pertumbuhan ekonomi Indonesia tahun 1975-2019. H3: Diduga bahwa ekspor migas, penanaman modal asing, utang luar negeri, dan inflasi secara simultan berpengaruh signifikan terhadap pertumbuhan ekonomi Indonesia tahun 1975-2019.

\section{METODE PENELITIAN}

Penelitian ini bertujuan untuk mengetahui bagaimana pengaruh ekspor migas, utang luar negeri, penanaman modal asing dan inflasi terhadap pertumbuhan ekonomi Indonesia tahun 19752019, sehingga akan menggunakan pendekatan asosiatif. Lokasi penelitian ini dilakukan di Indonesia untuk melihat perkembangan pertumbuhan ekonomi di Indonesia yang berfluktuatif dari tahun ke tahun. Data-data yang digunakan pada penelitian ini yaitu data yang diambil melalui website resmi World Bank yaitu www.worldbank.org, dan Badan Pusat Statistik (BPS). Jenis data yang digunakan dalam penelitian ini adalah data kualitatif dan kuantitatif. Data kualitatif dalam penelitian ini adalah data yang tidak berbentuk angka-angka dan tidak dapat diukur dengan satuan hitung, yaitu penjelasan keterangan-keterangan yang berbentuk kata, kalimat, skema, dan gambar mengenai variabel yang diteliti. Data kuantitatif dalam penelitian ini adalah nilai ekspor migas, penanaman modal asing, utang luar negeri dan inflasi terhadap pertumbuhan ekonomi. Sumber data dalam penelitian ini berasal dari

Pengaruh Ekspor Migas, Penanaman Modal Asing, Utang Luar Negeri, dan Inflasi Terhadap Pertumbuhan Ekonomi Indonesia, Insyai Rina Warer danNi Putu Wiwin Setyari 
data sekunder diperoleh dari hasil publikasi dari data yang sudah dikumpulkan dari instansi-instansi terkait antara lain website: Badan Pusat Statistik (BPS) www.bps.go.id, dan World Bank www.worldbank.org. Penelitian ini menggunakan data tahunan dalam bentuk deret waktu (time series) tahun 1975-2019 dengan total jumlah pengamatan sebanyak 45 pengamatan. Penelitian ini menggunakan metode pengumpulan data observasi non perilaku, yaitu pengumpulan data dengan cara membaca, menyalin dan mengolah dokumen, serta catatan tertulis yang ada (Sugiyono, 2002). Analisis data yang digunakan adalah metode regresi linear berganda sebagai alat ekonometrika untuk mengambarkan karakterisktik dari sebuah sampel ataupun lokasi yang diamati dengan bantuan SPSS (Statistical Product and Service Solutions) 26 for windows. Data penelitian juga akan dianalisis dengan analisis penelitian deskriptif merupakan suatu metode penelitian yang dilakukan dengan tujuan utama untuk membuat gambaran atau deksripsi tentang suatu keadaan secara objektif

\section{HASIL DAN PEMBAHASAN}

Pertumbuhan ekonomi merupakan suatu indikator yang penting untuk menilai kinerja suatu perekonomian, terutama dalam melakukan analisis tentang hasil pembangunan ekonomi yang telah dilaksanakan suatu daerah tertentu. Ekonomi dikatakan mengalami pertumbuhan jika produksi barang dan jasa meningkat dari tahun sebelumnya.

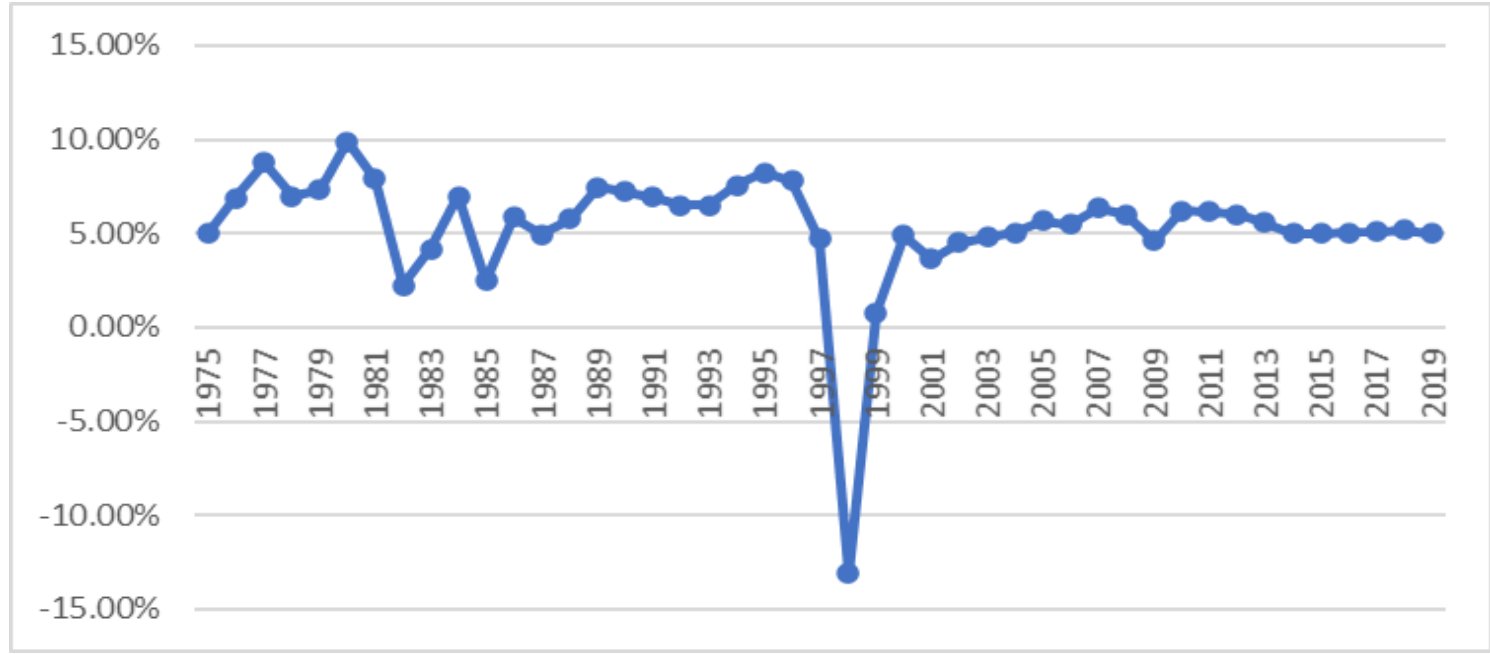

Sumber: World Bank, 2021

\section{Gambar 1.}

\section{Laju Pertumbuhan Ekonomi (dalam persen)}

Pada Gambar 1, menunjukkan bahwa pertumbuhan ekonomi Indonesia mulai tahun 1975 cukup stabil. Pertumbuhan terendah terjadi pada tahun 1998 mencapai $-13,13$ persen yang karena dilanda krisis moneter akibat terjadinya pelemahan nilai tukar bath Thailand terhadap dollar Amerika Serikat, kemudianmenyebabkan terjadinya depresiasi mata uang beberapa negara ASEAN termasuk di Indonesia. Pada tahun-tahun berikutnya pertumbuhan ekonomi Indonesia mengalami tren positif, meskipun sempat menurun sebesar 4,63 persen pada tahun 2009 akibat krisis global pada tahun 2008, selanjutnya pada tahun 2010 terjadi penigkatan sebesar 6,22 persen. Namun, sejak tahun 2011 pertumbuhan ekonomi Indonesia kembali terjadi penurunan secara terus-menerus sampai tahun 2019 hingga sebesar 5,03 persen.

Pengaruh Ekspor Migas, Penanaman Modal Asing, Utang Luar Negeri, dan Inflasi Terhadap Pertumbuhan Ekonomi Indonesia, Insyai Rina Warer danNi Putu Wiwin Setyari 
Pertumbuhan ekonomi Indonesia mengalami penrurunan sebesar 4,63 persen pada tahun 2009 karena pengaruh krisis global, pada tahun 2010 meningkat mencapai 6,22 persen akibat booming dua komoditas sekaligus, yakni batubara dan Crude Palm Oil (CPO). Setelah tahun 2010, keadaan perekonomian berbalik arah ketika harga-harga komoditas dunia, termasuk CPO dan batu bara sebagai komoditas utama ekspor bagi Indonesia mengalami penurunan karena peningkatan stok minyak sawit di negeri penghasil utama minyak sawit yaitu Indonesia dan Malaysia. Menurunnya harga komoditas utama ekspor Indonesia juga diakibatkan oleh penurunan harga minyak dunia (WOP). Turunnya harga minyak disebabkan karena adanya persaingan antara negara Amerika Serikat yang memproduksi dan memiliki shale gas dan shale oil dalam jumlah yang banyak, serta OPEC memiliki stok minyak bumi yang tidak mau menurunkan produksinya, sehingga pasokan berlimpah.

Ekspor akan memperbesar kapasitas konsumsi suatu negara meningkatkan output dunia, serta menyajikan akses ke sumber-sumber daya yang langka dan pasar-pasar internasional yang potensial untuk berbagai produk ekspor yang mana tanpa produk-produk tersebut, maka negaranegara miskin tidak akan mampu mengembangkan kegiatan dan kehidupan perekonomian nasionalnya.

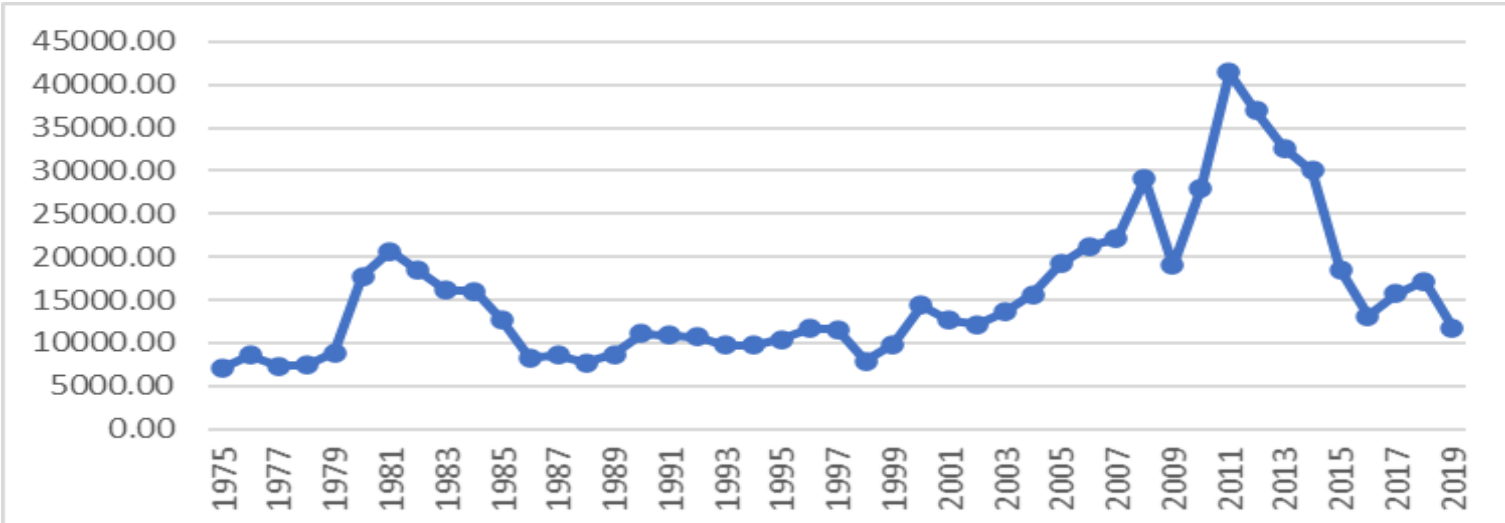

Sumber: Badan Pusat Statistik, 2021

Gambar 2.

Perkembangan Ekspor Migas Indonesia (dalam Juta Dollar)

Berdasarkan grafik diatas, ekspor migas Indonesia mengalami tren yang naik, hal ini bukan karna produksi ekspor migas Indonesia yang naik melainkan harga minyak yang meningkat. Seperti yang diketahui, bahwa Indonesia merupakan negara importir sejak memasuki tahun 2003. Minyak dan gas bumi mempunyai dua peran yang sangat penting dalam perekonomian Indonesia yaitu pertama sebagai sumber devisa bagi negara kemudian sebagai sumber energi untuk kegiatan ekonomi dalam negeri. Seiring dengan meningkatnya perkembangan ekonomi dan pertumbuhan jumlah penduduk Indonesia mengakibatkan konsumsi energi dari migas semakin meningkat, sedangkan produksi minyak dan gas bumi Indonesia masih sangat terbatas.

Penanaman modal asing (PMA) memegang peranan dalam proses pembangunan ekonomi pada negara maju dan negara berkembang. Adanya investasi asing diperlukan dalam pertumbuhan ekonomi Indoensia, makadari itu, pemerintah terus mengupayakan agar investor teratrik untuk menanamkan modalnya di Indonesia agar tercipta iklim investasi yang kondusif melalui derelugasi. 


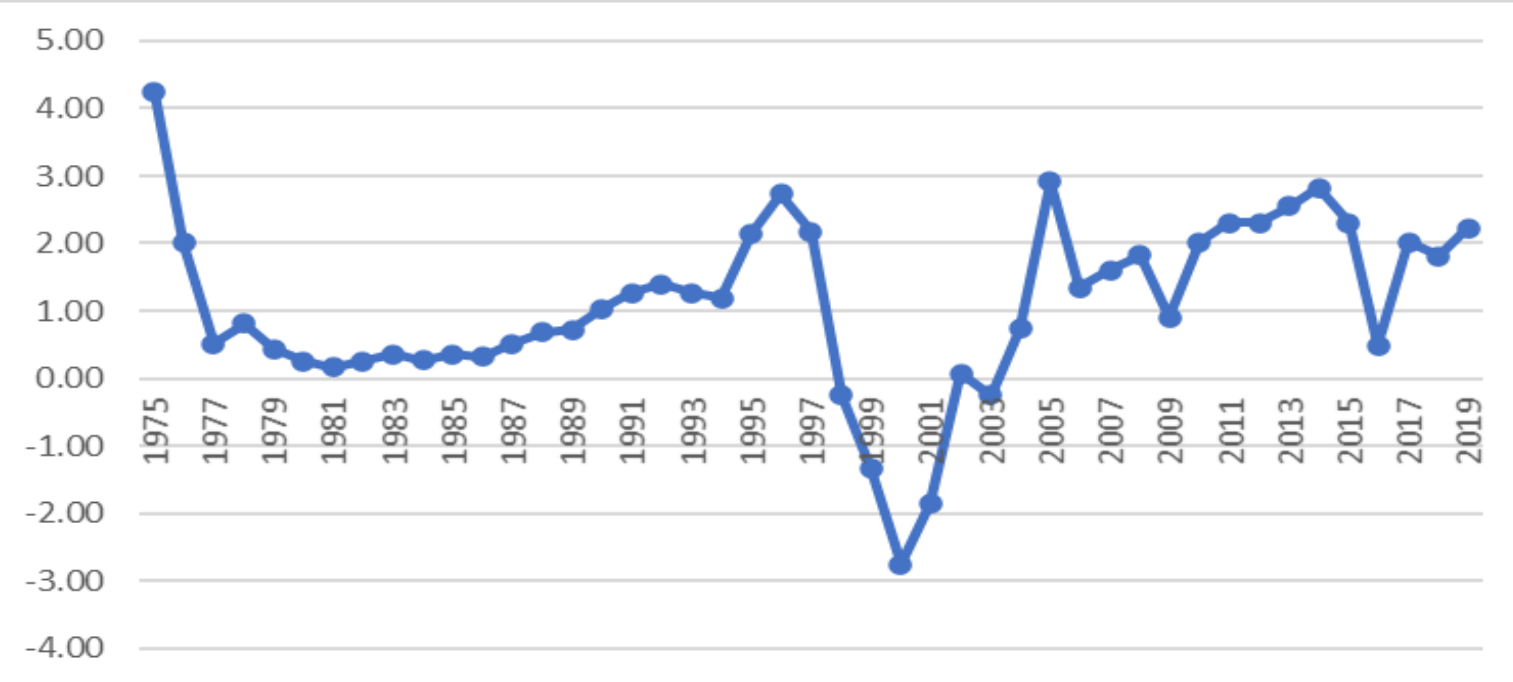

Sumber: World Bank(2021)

Gambar 3.

Perkembangan Penanaman Modal Asing Indonesia tahun 1975-2019 (dalam Persen)

Perkembangan penanaman modal asing Indonesia dari tahun 1975-2019 mengalami tren yang semakin menurun. Jika dilihat dari tahun 1975 Penananaman modal asing mencapai $4.24 \%$ karena pada tahun itu sudah terjadi liberalisasi investasi asing yang masuk ke Indonesia sehingga perekonomian kondusif dan berdampak terhadap pertumbuhan ekonomi. Akan tetapi, memasuki tahun 1997 penanaman modal asing Indonesia mulai menurun, hal ini disebabkan adanya peristiwa sejarah yaitu krisis ekonomi. Pertumbuhan ekonomi yang lambat sejak krisis disebabkan oleh belum pulihnya investasi. Investasi (berupa pembentukan modal tetap bruto - tidak termasuk perubahan stok) hanya tumbuh rata-rata 2,7 persen antara tahun 2001 - 2003 (dengan harga dasar tahun 1993), jauh lebih rendah dibandingkan dengan tahun 1991 - 1997 yang tumbuh rata-rata 10,6 persen per tahun. Dengan pertumbuhan yang lambat ini, tingkat investasi riil dalam tahun 2003 baru mencapai sekitar 75 persen dibandingkan tahun 1996, sebelum krisis. Peranan investasi dalam pembentukan produk domestik bruto (PDB) menurun dari 29,6 persen pada tahun 1996 menjadi 19,7 persen pada tahun 2003. Pada tahun 2004, peranan investasi dalam pembentukan PDB mengalami peningkatan, tetapi masih sangat awal untuk menjamin pertumbuhan yang berkesinambungan.

Kondisi ekonomi yang buruk, tentunya juga akan mempengaruhi psikologi investor untuk mempertimbangkan kembali keputusan yang sudah diambil. Penelitian yang dilakukan oleh Ksantini \& Boujelbene (2014) menunjukkan bahwa terdapat pengaruh terjadinya krisis moneter terhadap pertumbuhan ekonomi dan investasi dan pengaruhnya adalah negatif

Utang luar negeri (ULN) Inoendia dibagi menjadi utang pemerintah dan utang swasta. Utang luar negeri yang digunakan dalam penelitian ini adalah utang luar negeri pemerintah. Utang luar negeri terjadi karena rendahnya akumulasi tabungan domestik sehingga dapat mengancam stabilitas perekonomian. Utang luar negeri memberi tekanan pada defisit anggaran dan cadangan devisa. Adapun tujuan adanya utang luar negeri yaitu sebagai dana pendamping dalam melaksanakan pembangunan, tetapi hal ini justru mengakibatkn adanya ketergantungan dalam pengadaan utang luar negeri dalam pembangunan di Indonesia. Peningkatan utang luar negeri terjadi karena pendapaan 
negara melalui ekspor belum dapat mencukupi kebutuhan dalam negeri, sedangkan impor terus meningkat.

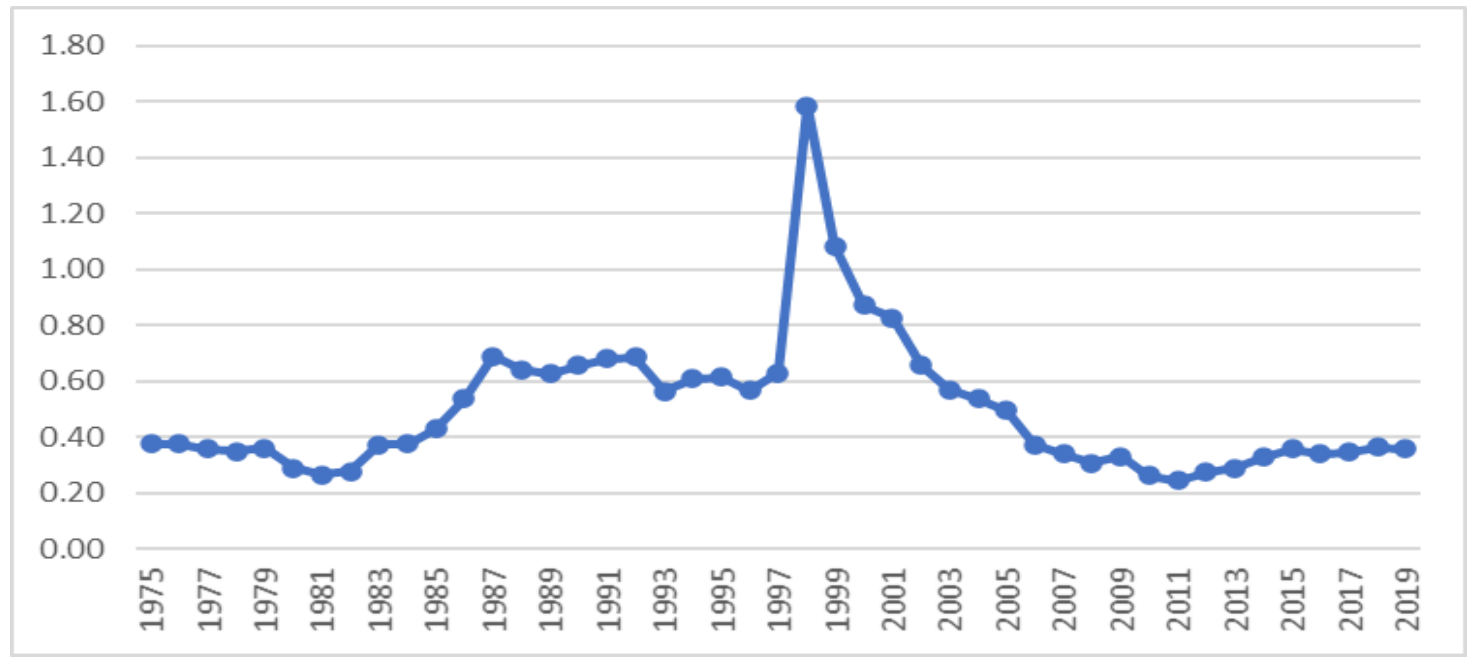

Sumber: World Bank, 2021

Gambar 4.

Perkembangan Utang Luar Negeri Pemerintah Indonesia Tahun 1975-2019 (dalam Persen)

Hasil penelitian menunjukkan perkembangan utang luar negeri Indonesia yang menunjukkan tren stabil yaitu di 0,38 \% dari tahun 1975-2019. Jika dilihat pada gambar, pada tahun 1998 utang luar negeri mengalami peningkatan yang sangat tinggi dibandingkan dengan tahun-tahun yang lain. Semakin bertambahnya jumlah utang, maka kinerja pemerintahan semakin dipertanyakan. Pada tahun 1998 terjadi peristiwa krisis moneter yang kemudian berlanjut menjadi krisis ekonomi, Bank Dunia mengindentifikasikan bahwa akumulasi utang swasta luar negeri Indonesia yang begitu cepat dari 1992 hingga Juli 1997 dengan jatuh tempo rata-rata hanya 18 bulan adalah salah satu penyebab utama krisis di era itu. Krisis ekonomi yang melanda Indonesia pada tahun 1997-1998 menjadikan utang luar negeri Indonesia meningkat drastis jika dihitung menggunakan mata uang rupiah. Mendiskusikan kenaikan akumulasi utang luar negeri mengakibatkan pemerintah harus mengambil utang luar negeri yang baru guna membayar utang luar negeri yang sudah jatuh tempo. Besarnya beban cicilan pokok dan bunga juga membebani dalam anggaran pendapatan dan belanja negara (APBN) (Galuh Widharma,2011).

Inflasi adalah suatu kecenderungan meningkatnya tingkat harga umum secara terus-menerus sepanjang waktu (Nanga, 2005). Menurut Saputra (2013), Inflasi mempengaruhi alokasi faktor produksi dan produk nasional serta distribusi pendapatan, ibarat dua sisi mata uang inflasi dapat berdampak positif dan negatif. Sisi positif dari inflasi adalah dapat menjadi stimulator pertumbuhan ekonomi. Kenaikan harga yang tidak dengan segera diikuti oleh kenaikan upah pekerja, akan berakibat pada meningkatnya gairah produksi dan pertumbuhan kesempatan kerja baru. Sisi negatif dari inflasi ialah cenderung akan meningkatkan harga barang secara umum, dan apabila kenaikan terjadi secara berlebihan akan menurunkan gairah produksi dan konsumsi serta beresiko memicu terjadi hiper inflasi dan berkurangnya volume ekspor suatu negara (Alfian, 2012). 


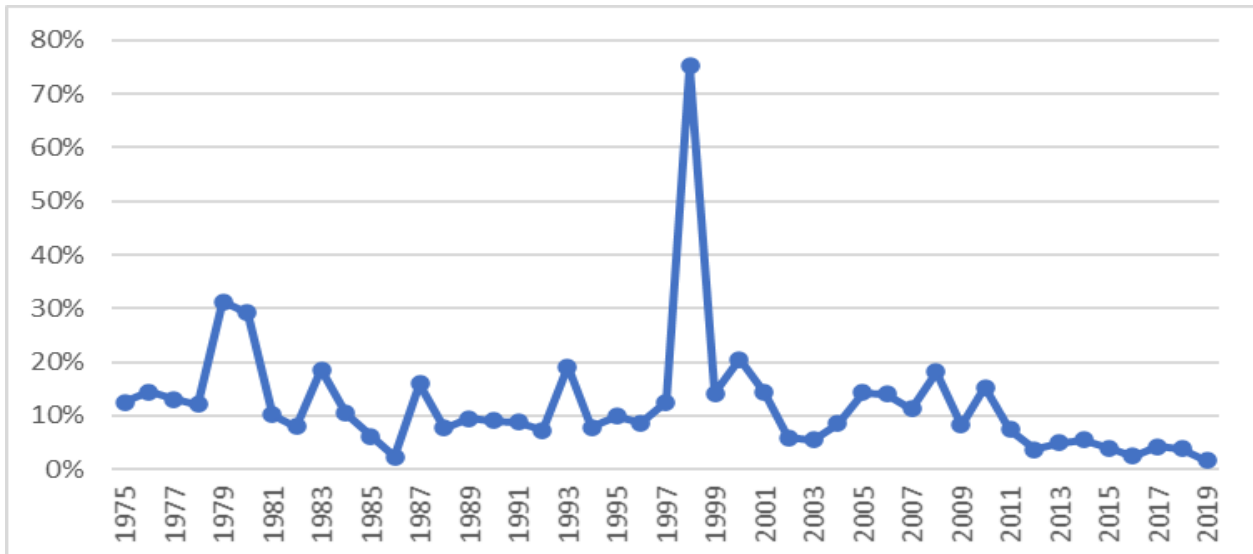

Sumber: World Bank, 2021

Gambar 5.

Perkembangan Inflasi Indonesia tahun 1975-2019 (dalamPersen)

Pada pertengahan tahun 1997 pondasi perekonomian Indonesia yang sudah dibangun sekian lama mengalami guncangan hebat. Krisis ekonomi yang diawali dengan krisis moneter telah "memporak-porandakan" perekonomian Indonesia. Pertumbuhan ekonomi yang tinggi terkontraksi hingga hanya mencapai angka $4.7 \%$ pada tahun 1997, kemudian merosot tajam menjadi sekitar $-13,1$ $\%$ pada tahun 1998. Krisis yang terjadi ini juga berimbas pada indikator makro lainnya seperti inflasi yang meningkat hingga mencapai angka $75 \%$, akibatnya berdampak sangat luas dengan timbulnya beragam tragedi sosial, politik, dan ekonomi yang hampir merata di seluruh penjuru tanah air. Tingginya angka inflasi ini menyebabkan tingkat harga terutama harga barang kebutuhan pokok melonjak drastis. akibatnya berdampak sangat luas dengan timbulnya beragam tragedi sosial, politik, dan ekonomi yang hampir merata di seluruh penjuru tanah air.

Seperti yang dipublikasikan oleh Bank Indonesia (2009), pentingnya pengendalian inflasi didasarkan pada pertimbangan bahwa inflasi tinggi dan tidak stabil memberikan dampak negatif kepada kondisi sosial ekonomi masyarakat. Pertama, inflasi yang tinggi akan menyebabkan pendapatan riil masyarakat akan terus turun sehingga standar hidup dari masyarakat juga turun. Kedua, inflasi yang tidak stabil akan menciptakan ketidakpastian bagi masyarakat dalam mengambil keputusan melakukan konsumsi, investasi dan produksi, yang pada akhirnya akan menurunkan pertumbuhan ekonomi. Ketiga, tingkat inflasi domestik yang lebih tinggi dibanding dengan tingkat inflasi di negara tetangga menjadikan tingkat bunga domestik riil menjadi tidak kompetitif sehingga dapat memberikan tekanan pada nilai rupiah

Tabel1.

Hasil Analisis Statistik Deskriptif

\begin{tabular}{llrrrr}
\hline & $\mathrm{N}$ & \multicolumn{1}{c}{ Minimum } & \multicolumn{1}{c}{ Maximum } & \multicolumn{1}{c}{ Mean } & Std. Deviation \\
\hline Pert.Ekonomi & 45 & -.13 & .10 & .0536 & .03283 \\
Ekspor Miga s & 45 & 7102.50 & 41477.00 & 15607.4844 & 8215.21449 \\
PMA & 45 & -2.76 & 4.24 & 1.0864 & 1.29565 \\
ULN & 45 & .25 & 1.59 & .5009 & .25003 \\
INF & 45 & .02 & .75 & .1217 & .11531 \\
\hline Valid N (listwise) & 45 & & & & \\
\hline
\end{tabular}

Sumber: Data Sekunder diolah 2021 
Berdasarkan Tabel 1 dapat dijelaskan jumlah data yang digunakan dalam penelitian ini berjumlah 45 data dengan rentang waktu selama tahun 1975-2019. Variabel dependen pertumbuhan ekonomi memiliki nilai tertinggi sebesar 0.10 persen pada tahun 1980 dan nilai terendah sebesar -0.13 persen pada tahun 1998 serta jumlah rata-rata untuk pertumbuhan ekonomi yaitu 0.0536 volatilitas dengan standar deviasi sebesar 0.03283. Variabel independent ekspor migas memiliki nilai tertinggi sebesar 41477.00 pada tahun 2011 dan nilai terendah sebesar 7102.50 pada tahun 1975 serta jumlah rata-rata ekspor migas yaitu 15607.4844 dengan standar deviasi sebesar 8215.21449 Nilai mean variabel ekspor migas lebih besar dari standar deviasi, sehingga dapat disimpulkan bahwa rata-rata dari seluruh data pada variabel independent mampu menggambarkan seluruh variabel dengan baik.

Penanaman modal asing memiliki nilai tertinggi sebesar 4.24 pada tahun 1975 dan nilai terendah sebesar -2.76 pada tahun 2000 serta jumlah rata-rata penanaman modal asing yaitu 1.0864 dengan standar deviasi sebesar 1.29565. Variabel utang luar negeri memiliki nilai tertinggi sebesar 1.59 pada tahun 1998 dan nilai terendah sebesar 0.25 pada tahun 2011 serta jumlah rata-rata utang luar negeri yaitu 0.5009 dengan standar deviasi sebesar 0.25003 . Nilai mean variabel utang luar negeri lebih besar dari standar deviasi, sehingga dapat disimpulkan bahwa rata-rata dari seluruh data pada variabel independent mampu menggambarkan seluruh variabel dengan baik. Terakhir, variabel inf lasi memiliki nilai tertinggi sebesar 0.75 persen pada tahun 1998 dan nilai terendah sebesar 0.02 persen pada tahun 2019 serta jumlah rata-rata inflasi yaitu 0.1217 dengan standar deviasi sebesar 0.11531. Nilai mean variabel inflasi lebih besar dari standar deviasi, sehingga dapat disimpulkan bahwa ratarata dari seluruh data pada variabel independent mampu menggambarkan seluruh variabel dengan baik.

Tabel 2.

Hasil Uji Simultan (Uji F)

\begin{tabular}{lllll}
\hline Model & $\mathrm{R}$ & R Square & Adjusted R Square & Std. Error of the Estimate \\
\hline 1 & $.774^{\mathrm{a}}$ & .599 & .558 & .02182 \\
\hline
\end{tabular}

a. Predictors: (Constant), INF, Ekspor Migas, PMA, ULN

b. Dependent Variable:Pertumbuhan Ekonomi

ANOVA $^{\mathrm{a}}$

\begin{tabular}{llccccc}
\hline Model & Sum of Squares & df & Mean Square & F & Sig. \\
\hline 1 & Regression & .028 & 4 & .007 & 14.907 & $.000^{\mathrm{b}}$ \\
& Residual & .019 & 40 & .000 & & \\
Total & .047 & 44 & & & \\
\hline
\end{tabular}

a.Dependent Variable: Pertumbuhan Ekonomi

b. Predictors: (Constant), INF, Ekspor Miga s, PMA, ULN

Sumber: Data Sekunder Diolah, 2021

Hasil uji nilai $\mathrm{R}^{2}$ sebesar 0,599 menunjukkan bahwa variabel ekspor migas, utang luar negeri, penanaman modal asing dan inflasi memiliki pengaruh yang cukup kuat terhadap pertumbuhan ekonomi. Memiliki arti bahwa 59,9\% variasi pertumbuhan ekonomi dipengaruhi oleh ekspor migas, utang luar negeri, penanaman modal asing dan inflasi, sedangkan 40,1\% dipengaruhi oleh faktor lain yang tidak dimasukkan dalam model. Hasil uji $\mathrm{F}$ menunjukkan sig 0,00 lebih kecil dari 5\%, yang 
memiliki arti bahwa secara simultan variabel ekspor migas, penanaman modal asing, utang luar negeri dan inflasi signifikan terhadap pertumbuhan ekonomi.

Uji normalitas bertujuan untuk menguji apakah dalam model regresi, variabel penganggu atau residual memiliki distribusi normal. Untuk menguji normalitas dalam penelitian ini peneliti menggunakan uji statistik dengan parametrik Kolmogorov-Smirnov Test $(K-S)$ dengan menggunakan bantuan program SPSS ver 26 for windows. Berdasarkan hasil uji diperoleh nilai statistik Kolmogorov-Smirnov adalah 0,090 dengan Sig (2-tailed) sebesar 0,200 lebih besar dari 0,05. Hal ini berarti bahwa data residual berdistribusi normal atau dapat dikatakan telah lolos uji normalitas.

Untuk menguji multikolinieritas dapat menggunakan aplikasi SPSS dengan melihat nilai VIF dari masing-masing variabel. Jika nilai VIF lebih rendah dari 10, maka dapat disimpulkan bahwa tidak ada multikolinieritas yang serius antara variabel independen dengan model. Hasil olah data diperoleh hasil perhitungan nilai pada kolom tolerance lebih dari 0,10 dan nilai pada kolom VIF lebih rendah dari 10 maka dapat disimpulkan bahwa tidak ada multikolinieritas antar variabel independen dalam model regresi.

Uji autokorelasi yang digunakan dalam penelitian ini adalah Uji Durbin-Watson (DW-Test). Pengujian ini dilakukan dengan menggunakan bantuan program SPSS ver 26 for windows. Hasil pengujian autokorelasi diperoleh nilai DW sebesar 1.158. penelitian ini menggunakan $\mathrm{n}$ (jumlah data) sebanyak 45 dan k (jumlah variabel independen) adalah 4, sehingga berdasarkan tabel Durbin-Watson diperoleh nilai $\mathrm{d}_{\mathrm{L}}=1,336$ dan $\mathrm{d}_{\mathrm{U}}=1,720$ sehingga diperoleh nilai $4-\mathrm{d}_{\mathrm{U}}=2,28$, maka dapat dirumuskan kriteria $0<\mathrm{DW}<4-\mathrm{d}_{\mathrm{U}}$ yaitu $(0<1,158<2,28)$. Hal ini menunjukkan data yang digunakan pada penelitian ini menunjukkan tidak terjadi autokorelasi positif.

Uji heteroskedastisitas dilakukan dengan metode Park menggunakan bantuan program SPS S ver 26 for windows. Berdasarkan hasil pengujian diperoleh nilai probabilitas signifikansi diatas 0,05 atau diatas tingkat kepercayaan 5\%, sehingga tidak ada satupun variabel independen yang signifikan secara statistik mempengaruhi variabel dependen nilai absolut $\mathrm{Y}$ atau $|\mathrm{Y}|$. Dapat disimpulkan bahwa model regresi diatas tidak mengandung adanya heteroskedastisitas.

Dalam penelitian ini terdapat 1 (satu) variabel dependen yaitu pertumbuhan ekonomi dan 4 (empat) variabel independent yaitu ekspor migas, penanaman modal asing, utang luar negeri dan inflasi. Uji signifikansi individual atau uji-t diperoleh sebagai berikut:

Tabel 3.

Hasil Uji Regresi

\begin{tabular}{|c|c|c|c|c|c|}
\hline \multirow[b]{2}{*}{ Model } & \multicolumn{2}{|c|}{ Unstandardized Coefficients } & \multirow{2}{*}{$\frac{\text { StandardizedCoefficients }}{\text { Beta }}$} & \multirow[b]{2}{*}{$\mathrm{t}$} & \multirow[b]{2}{*}{ Sig. } \\
\hline & B & Std.Error & & & \\
\hline 1 (Constant) & .124 & .014 & & 8.614 & .000 \\
\hline Eks Migas & $-1.014 \mathrm{E}-6$ & .000 & -.254 & -2.174 & .036 \\
\hline PMA & -.001 & .003 & -.055 & -.474 & .638 \\
\hline ULN & -.081 & .019 & -.620 & -4.186 & .000 \\
\hline INF & -.098 & .036 & -.345 & -2.766 & .009 \\
\hline
\end{tabular}

a.Dependent Variable: Pertumbuhan Ekonomi

Sumber: Data Sekunder Diolah, 2021

Pengaruh Ekspor Migas, Penanaman Modal Asing, Utang Luar Negeri, dan Inflasi Terhadap Pertumbuhan Ekonomi Indonesia, Insyai Rina Warer danNi Putu Wiwin Setyari 
Ekspor migas menunjukkan nilai t-hitung -2.174 lebih besar dari t-tabel sebesar -2.021 dengan nilai signifikansi sebesar 0.036 lebih kecil dari 0.05 yang berarti ekspor migas berpengaruh signifikan terhadap pertumbuhan ekonomi. Nilai koefisien bernilai negatif sebesar -1.014E-6 yang menunjukkan bahwa variabel ekspor migas memiliki hubungan yang negatif terhadap pertumbuhan ekonomi. Hal ini berarti bahwa, apabila variabel independen ekspor migas mengalami kenaikan sebesar 1 juta US\$ sementara variabel independen utang luar negeri, penanaman modal asing dan inflasi bersifat tetap maka variabel pertumbuhan ekonomi akan mengalami penurunan sebesar -1.014E-6. Hasil penelitian mengindikasikan bahwa alokasi volume ekspor migas pada periode tertentu pada penelitian ini tidak tepat sasaran dalam pelaksanaanya, selain itu nilai negatif yang didapat menunjukkan bahwa ekspor yang dilakukan terus menurun sesuai dengan produksi minyak yang kian menurun pula. Penurunan produksi minyak lebih dipengaruhi oleh faktor lapangan tambang minyak bumi di Indonesia yang mengalami natural declining atau dengan kata lain lapangan sumur minyak bumi menua sehingga lifting dan produksi minyak nasional tiap periode penelitian. Faktor harga minyak dunia yang tidak menentu dan tingkat efisiensi energi Indonesia yang buruk memperparah keadaan ini.

Indonesia yang sudah menjadi negara pengimpor bersih minyak dari tahun 2004 harus lebih mengutamakan alokasi volume migas ke konsumsi domestik yang sangat tinggi hingga dapat menekan jumlah impor khususnya minyak yang sedemikian besar sehingga pengeluaran devisa atas pembelian impor minyak bisa berkurang. Pada sisi ekspor gas Indonesia pada awal hingga akhir penelitian menunjukkan performa yang cukup baik dan dapat diandalkan dalam menunjang tambahan pendapatan negara. Namun adanya rencana kebijakan dari pemerintah tentang pembatasan penjualan ekspor gas bumi membuat nilai ekspor gas berkurang tiap tahunnya dengan alasan bahwa kebutuhan gas domestik akan meningkat drastic dan akan menyebabkan Indonesia mengimpor gas secara lebih besar, seiring dengan meluasnya penggunaan gas bumi sebagai sumber energi.

Penanaman modal asing menunjukkan nilai -0.474 lebih kecil dari t-tabel -2.021 dengan nilai signifikansi sebesar 0.638 lebih besar dari 0.05 yang berarti penanaman modal asing berpengaruh tidak signifikan terhadap pertumbuhan ekonomi. Nilai koefisien bernilai negatif sebesar $-0.001 \mathrm{y}$ ang menunjukkan bahwa variabel penanaman modal asing memiliki hubungan yang negatif terhadap pertumbuhan ekonomi. Hal ini berarti bahwa, apabila penanaman modal asing mengalami kenaikan sebesar 1 persen maka pertumbuhan ekonomi akan turun sebesar -0.001. Hubungan yang negatif ini tidak sesuai dengan hipotesis diawal penelitian yang menyatakan bahwa variabel penanaman modal asing mempunyai hubungan yang positif terhadap pertumbuhan ekonomi. Menurut laporan kajian tengah tahun Institute for Development of Economic and Finance (INDEF) tahun 2019 terdapat beberapa factor yang menyebabkan PMA belum memiliki implikasi yang besar terhadap pertumbuhan ekonomi Indonesia. Pertama, pemerintah dinilai hanya mampu menarik investor-investor yang ada di sektor tersier yang sifatnya padat modal. Sehingga kontribusi investasi sifatnya padat modal untuk pertumbuhan ekonomi tidak signifikan. Kedua, investasi asing yang masuk ke Indonesia belum efisien jika dilihat dari nilai Incremental Capital Output Ratio (ICOR) pada tahun 2016-2018 masih berada diangka lebih dari 6. Angka ini sangat jauh jika dibandingkan nilai ICOR tahun 2008 yang menyentuh angka 3.8. Akibatnya realisasi investasi belum mampu mendorong pertumbuhan sektor industri untuk menjadi roda penggerak utama (primer mover) ekonomi nasional (Laporan Kajian Tengah Tahun INDEF, 2019).

Menurut Tambunan (2011) dalam Shopia \& Sulasmiyati (2018) terdapat beberapa factor yang menyebabkan Indonesia tidak lagi menjadi tujuan utama investor untuk melakukan investasi penanaman modal asing. Faktor penghambat tersebut yakni, kondisi infrastruktur dan logistic yang

Pengaruh Ekspor Migas, Penanaman Modal Asing, Utang Luar Negeri, dan Inflasi Terhadap Pertumbuhan Ekonomi Indonesia, Insyai Rina Warer danNi Putu Wiwin Setyari 
buruk, kualitas SDM yang kurang kompetensi, kebijakan ekonomi yang kurang kondusif, tidak adanya kepastian hukum, birokrasi yang tidak efisien.

Utang luar negeri menunjukkan nilai -4.186 lebih besar dari t-tabel sebesar -2,021 dengan nilai signifikansi sebesar 0.000 lebih kecil dari 0.05 yang berarti utang luar negeri berpengaruh signifikan terhadap pertumbuhan ekonomi. Nilai koefisien bernilai negatif sebesar -0.081 yang menunjukkan bahwa variabel utang luar negeri memiliki hubungan yang negatif terhadap pertumbuhan ekonomi. Hal ini berarti bahwa, apabila utang luar negeri mengalami kenaikan sebesar $1 \%$ maka variabel pertumbuhan ekonomi akan mengalami penurunan sebesar -0.081 persen. Hubungan yang negatif ini tidak sesuai dengan hipotesis diawal penelitian yang menyatakan bahwa variabel utang luar negeri mempunyai hubungan yang positif terhadap pertumbuhan ekonomi. Menurut ekuivalensi Ricardian menyebutkan bahwa peningkatan ULN tidak akan meningkatkan pertumbuhan ekonomi. Hal ini disebabkan karena masyarakat tidak akan menambah pengeluarannya, karena mereka akan mewaspadai peningkatan pajak dimasa depan. Peningkatan pajak dimasa depan akan digunakan untuk membiayai cicilan dan bunga utang luar negeri yang dilakukan pemerintah (Mankiw, 2007).

Dalam jangka pendek, utang luar negeri dan pertumbuhan ekonomi memiliki hubungan yang negatif, karena dalam periode tersebut akumulasi utang luar negeri Indonesia sangat besar. Makadari itu, penerimaan pinjaman utang luar negeri pemerintah tidak akan efektif untuk mendorong pertumbuhan ekonomi. Utang luar negeri pemerintah juga digunakan untuk membayar cicilan utang dan bunganya. Dalam jangka Panjang, utang menjadi persoalan yang perlu dipecahkan dalam pemulihan ekonomi. Kegagalan Indonesia dalam mengelola utang pada masa lampau menyebabkan sebagian besar masyarakat mulai menolak akan adanya utang luar negeri. Hal ini menimbulkan persepsi bahwa utang luar negeri akan menjadi sumber negatif bagi ekonomi sehingga usaha pemulihan pertumbuhan ekonomi menjadi lebih sulit. Menurut Elbadawi et.al (1997), dalam penelitiannya membuktikan bahwa akumulasi pinjaman luar negeri terjadi karena adanya peningkatan kebutuhan untuk melunasi utang pada masa yang lalu berdampak negatif terhadap investasi dan pertumbuhan ekonomi setelah melewati batas tertentu.

Inflasi menunjukkan nilai t-hitung sebesar -2.766 lebih besar dari t-tabel sebesar -2.021 dengan signifikansi 0.009 lebih kecil dari 0.05 yang berarti inflasi berpengaruh signifikan terhadap pertumbuhan ekonomi. Nilai koefisien bernilai negatif sebesar -0.098 yang menunjukkan bahwa variabel inflasi memiliki hubungan yang negatif dengan pertumbuhan ekonomi. Hal ini berarti bahwa, apabila perubahan inflasi naik 1 persen maka terjadi perubahan pertumbuhan ekonomi akan bergerak kearah yang berbeda (turun) sebesar -0.098 persen. Hasil penelitian ini sesuai dengan penelitian yang dilakukan oleh Khoirina Laiylana (2013) menunjukkan bahwa inflasi berpengaruh negatif terhadap pertumbuhan ekonomi di Indonesia. Bank Indonesia menuliskan bahwa inflasi yang tinggi menyebabkan pendapatan riil masyarakat akan terus menurun sehingga standart hidup dari masyarakat juga turun. Hal ini akan mempengaruhi keputusan masyarakat melakukan konsumsi, investasi, dan produksi sehingga akan menurunkan pertumbuhan ekonomi.

Kenaikan harga menyebabkan barang-barang didalam negeri tidak dapat bersaing dipasar internasional sehingga ekspor menurun sebaliknya harga-harga produksi dalam negeri yang semakin tinggi sebagai akibat inflasi menyebabkan barang-barang impor menjadi relatif murah maka impor akan lebih banyak dilakukan. Menurunnya ekspor dan meningkatnya impor akan menyebabkan ketidakseimbangan dalam aliran mata uang asing, dan kedudukan neraca pembayaran akan memburuk yang berpengaruh terhadap pendapatan nasional (Sukirno, 2005).

Hasil dari penelitian ini menunjukkan bahwa ekspor migas berpengaruh signifikan negatif terhadap apresiasi pertumbuhan ekonomi Indonesia. Ekspor migas dengan indikator ekspor minyak dan ekspor gas berpengaruh signifikan karena sektor migas berperan penting dalam pembentukan GDP sebagai indicator pertumbuhan ekonomi. Arah negatif yang ditunjukkan menggambarkan alokasi

Pengaruh Ekspor Migas, Penanaman Modal Asing, Utang Luar Negeri, dan Inflasi Terhadap Pertumbuhan 
ekspor migas yang tidak tepat ditengah volume konsumsi energi dalam negeri sedang meningkat tajam dan harga minyak pada periode tertentu yang cenderung turun serta produksi yang kian menunjukkan declining tiap periodenya.

Penanaman modal asing dalam penelitian ini memiliki pengaruh tidak signifikan dan negatif terhadap pertumbuhan ekonomi Indonesia. Pengembangan penanaman modal asing di Indonesia masih terhambat oleh rumitnya proses pengurusan izin-izin akibat birokrasi yang berbelit-belit serta kurangnya keterpaduan koordinasi antar departemen yang terkait. Rendahnya kualitas dan produktivitas sumber daya manusia sehingga rencana alih teknologi belum terlaksana dengan baik, serta terjadinya persaingan yang semakin ketat dalam menarik investasi asing oleh negara maju maupun negara berkembang. salah satu implikasi dalam pembangunan di Indonesia, pemerintah mendorong penanaman investasi dan hal membuat investasi tumbuh subur di Indonesia. Pemerintah Indonesia berpijak dari teori Harrod-Domar, sampai membuat suatu lembaga yaitu Penanaman Modal Nasional, karena langkah ini dianggap sebagai langkah strategis untuk pertumbuhan dan pemban guan ekonomi.

Hasil dari penelitian ini menunjukkan bahwa utang luar negeri berpengaruh signifikan negatif terhadap pertumbuhan ekonomi Indonesia. Hubungan yang negatif antara utang luar negeri dengan pertumbuhan ekonomi karena selama periode tersebut akumulasi utang luar negeri Indonesia sangat besar sehingga walaupun ada penerimaan pinjaman utang luar negeri pemerintah tidak akan efektif untuk mendorong pertumbuhan ekonomi. Utang luar negeri pemerintah yang diterima juga digunakan lagi untuk membayar cicilan utang dan bunganya.

Inflasi dalam penelitian ini memiliki pengaruh negatif terhadap pertumbuhan ekonomi Indonesia. Yang memiliki arti bahwa Inflasi atau kenaikan harga-harga menimbulkan efek yang buruk terhadap perdagangan. Kenaikan harga menyebabkan barang-barang negeri itu tidak dapat bersaing di pasar internasional sehingga ekspor menurun. Sebaliknya, harga-harga produksi dalam negeri yang semakin tinggi sebagai akibat inflasi menyebabkan barang-barang impor menjadi relatif murah maka impor akan lebih banyak dilakukan. Menurunnya ekspor dan meningkatnya impor akan menyebabkan ketidakseimbangan dalam aliran mata uang asing, dan kedudukan neraca pembayaran akan memburuk yang berpengaruh terhadap pendapatan nasional (Sukirno, 2005:339).

\section{SIMPULAN DAN SARAN}

Berdasarkan hasil analisis dan pembahasan yang telah diuraikan sebelumnya, maka dapat ditarik kesimpulan bahwa secara parsial variabel ekspor migas berpengaruh secara signifikan terhadap pertumbuhan ekonomi Indonesia. Koefisien variabel ekspor migas bertanda negatif artinya ekspor migas menyebabkan pertumbuhan ekonomi menurun. Secara parsial variabel penanaman modal asing berpengaruh tidak signifikan terhadap pertumbuhan ekonomi Indonesia. Koefisien variabel penanaman modal asing bertanda negatif artinya penanaman modal asing menyebabkan menurunnya pertumbuhan ekonomi di Indonesia. Rendahnya kualitas dan produktivitas sumber daya manusia sehingga rencana alih teknologi belum terlaksana dengan baik, serta terjadinya persaingan yang semakin ketat dalam menarik investasi asing baik oleh negara maju maupun negara berkembang. Secara parsial variabel utang luar negeri berpengaruh secara signifikan terhadap pertumbuhan ekonomi Indonesia. Koefisien variabel utang luar negeri bertanda negatif artinya utang luar negeri menyebabkan menurunnya pertumbuhan ekonomi di Indonesia. Hal ini dikarenakan utang pada dasarnya dibutuhkan pada tingkat yang wajar. Utang tambahan akan berdampak positif pada pertumbuhan ekonomi sampai pada titik tertentu. Dalam hal ini, ULN adalah kebutuhan normal setiap negara. Namun bila stok utang melebihi batas maka peningkatan ULN mulai membawa dampak negative terhadap pertumbuhan ekonomi. Secara parsial variabel inflasi berpengaruh secara signifikan

Pengaruh Ekspor Migas, Penanaman Modal Asing, Utang Luar Negeri, dan Inflasi Terhadap Pertumbuhan Ekonomi Indonesia, Insyai Rina Warer danNi Putu Wiwin Setyari 
terhadap pertumbuhan ekonomi di Indonesia. Koefisien variabel inflasi bertanda negatif artinya inflasi akan menyebabkan pertumbuhan ekonomi menurun jika tidak terkendali. Secara simultan variabel ekspor migas, penanaman modal asing, utang luar negeri dan inflasi mempengaruhi pertumbuhan ekonomi Indonesia. Hal ini didukung oleh nilai $\mathrm{R}^{2}$ sebesar 0,599 yang memiliki arti bahwa 59,9 persen variasi pertumbuhan ekonomi dipengaruhi oleh ekspor migas, penanaman modal asing, utang luar negeri dan inflasi, sedangkan sisanya 40,1 persen dipengaruhi oleh faktor lain yang tidak dimasukkan didalam model.

\section{REFERENSI}

Arifin, Imamul \& Gina, Ha di. (2009). Membuka Cakrawala Ekonomi. Jakarta: Sa lemba Empat Arsya d, Lincolin. (2004). Ekonomi Pembangunan. Yogyakarta: STIE - YKPN.

Atmadja, A. S. (2000). Utang Luar Negeri Pemerintah Indonesia: Perkembangan dan Dampaknya. Jurnal Akuntansidan Keuangan, 2(1), 83-94.

Barro, R. J. (2013). Inflation and economic growth. Annals of Economics \& Finance, 14(1). B orenstein E., Gregorio J., Lee J. (1998), 'How does foreign direct investment a ffect economic growth?', Journal of International Economics, 45(1), 115-135

Elbadawi, I., Ndulu, B. J., \& Ndung'u, N. (1997). Debt overhang and economic growth in Sub -Sa haran Af rica . Externalfinance for low-income countries, 49-76.

Fitria ni, E. (2019). Analisis Pengaruh Perdagangan Internasional Terhadap Pertumbuhan Ekonomi In do ne sia. Jurisma: JurnalRiset Bisnis \& Manajemen, 9(1), 17-26

Handayani, T. (2011). Faktor-faktor yang Mempengaruhi Pertumbuhan Ekonomi di Indonesia Perio de 1999 2008 (Doctoral dissertation, UPN" Vetera n" Yogyakarta).

Hasmarini, M. I., \& Murtiningsih, D. (2017). Causa lity Analysis of Non-Oil Exports by Economic Growth Method Using Final Prediction Error. Journal of Economic Development: Economic Issues and Development Studies, 4 (2), 147-161.

Mankiw, N. Gregory. (2007). Makro Ekonomi, Edisi Keenam. Jakarta: Erlangga.

Nanga, Muana. (2005). Makroekonomi. Teori, Masalah dan Kebijakan. Edisi Kedua. Jakarta: PT. Rajagrafin do Persada

Putra, G. N. A., \& Sutrisna, I. K. (2017). Pengaruh ProduksiDan Inflasi TerhadapEk spor Da n Pertumbuhan Ekonomi Di Indonesia. E-Jurnal Ekonomi Pembangunan Universitas Udayana, 6(11), 2103-2351.

Rudriger, Dornbush. (2006). Ekonomi Makro. Edisi Kedelapan. Jakarta: Media GlobalEdukasi

Sa putra,kurniawan.2013.Analisis Faktor-Faktor Yang Mempengaruhi Inflasi Di Indonesia2007-2012. Sk rip si sa rja na pada program sarjana fakultas ekonomi Universitas Diponegoro Semarang.

Shopia, A., \& Sulasmiyati, S. (2018). Pengaruh Foreign Direct Investment, Ekspor, Da n Utang Luar Negeri Terhadap Pertumbuhan Ekonomi Asean (Studi Pada Produk Domestik Bruto Indonesia, Malaysia, Dan

Thailand Periode Tahun 2007-2016). JurnalAdministrasi Bisnis, 61(3), 20-28.

Sugiyono, FX (2017). Balance of payments: Concepts, methodology and implementation (Vol. 4). Kebanksentralan Center for Education Studies (PPSK) Bank Indonesia

Sukirno, Sadono. (2005). Makroekonomi Modern:Perkembangan Pemikiran DariKla sik Hingga Key nesian Baru. Jakarta: Raja Grafindo Pustaka

Sukirno, Sadono. (2011). Ekonomi Pembangunan Proses, Masalah dan Dasar Kebijakan. Prenada Media Grup : Jakarta

Todaro, M. P., \& Smith, S. C. (2006). Pembangunan ekonomi. Jakarta: Erlangga.

Untoro, Joko. (2010). Ekonomi Makro. Jakarta: Kawah Media

Widharma, I. W. G. IMKSB, dan AAIN Marhaeni.(2011). Utang Luar Negeri Pemerintah Indone sia: Kajian Terhadap Faktor-Faktor Yang Berpengaruh. Ekonomi.

Pengaruh Ekspor Migas, Penanaman Modal Asing, Utang Luar Negeri, dan Inflasi Terhadap Pertumbuhan Ekonomi Indonesia, Insyai Rina Warer danNi Putu Wiwin Setyari 